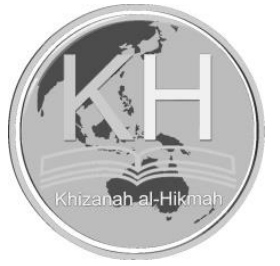

\title{
PENGALAMAN INFORMASI PEMILIH PEMULA MENGGUNAKAN MEDIA SOSIAL SEBAGAI SARANA PEMBELAJARAN POLITIK DALAM MENENTUKAN PILIHAN CALON PRESIDEN
}

\author{
Yanuar Yoga Prasetyawan* \\ *Program Studi Ilmu Perpustakaan, Fakultas Ilmu Budaya, Universitas Diponegoro \\ Email: yanuaryoga@live.undip.ac.id
}

(Submitted: 14-10-2019, Revised: 14-10-2019, Accepted: 21-04-2020)

DOI: $10.24252 /$ kah.v8i1a3

\begin{abstract}
ABSTRAK: Media sosial merupakan suatu hal yang tidak dapat dipisahkan dari kehidupan sehari-hari para pemilih pemula (digital native). Digital native cenderung menggunakan media sosial sebagai wadah belajar, tidak terkecuali dalam konteks mencari informasi mengenai politik. Media sosial digunakan sebagai media untuk belajar dan mengenal pasangan calon presiden dan wakil presiden. Melalui media sosial tersebut para pemilih pemula baik secara sengaja ataupun tidak, pasti akan berinteraksi dengan informasi seputar politik pencalonan presiden dan wakil presiden. Penelitian ini bertujuan untuk menangkap gambaran pengalaman informasi pemilih pemula menggunakan media sosial sebagai sarana pembelajaran politik dalam menentukan pilihan calon presiden dan wakil Presiden. Metode penelitian yang digunakan adalah metode kualitatif dengan pendekatan fenomenografi. Wawancara semi terstruktur digunakan sebagai teknik pengumpulan data. Hasil penelitian menujukan bahwa pengalaman informasi para pemilih pemula menggunakan media sosial sebagai media untuk mempelajari profil calon presiden, belajar berdemokrasi dengan berpendapat dalam kolom komentar, serta belajar menganalisis dan mengidentifikasi berita palsu seputar pemilu.
\end{abstract}

Kata kunci: Pengalaman informasi; media sosial; pemilih pemula; pemilihan presiden

\section{IDENTIFYING THE FIRST TIME EXPERIENCE OF NEW VOTERS WHO HAVE USED SOCIAL MEDIA TO UNDERSTAND THE INDONESIAN PRESIDENTIAL ELECTION}

\begin{abstract}
Social media has become an important part for most of people nowadays. It has been used for many purposes such as sharing and looking for information. This research is looking for the information experience of first-time voters after the presidential election. It seeks to understand how this group of voters have used social media for finding and using information about the Indonesian Presidential Candidates, and to what extend the information they get have influence their opinion about the two candidates. This research employed qualitative methods by using phenomenography approach. Semi-structured interview was used to collect data. The findings show that most of the first-time voters used social media to get to know better about the two candidates. It was one of their information sources when they need information about the presidential candidate profiles. Secondly, social media is the common place for most of the participants for sharing and expressing their opinions and ideas related to the candidates. Most interestingly, it was through social media that some participants have recognize that some information that are available online not necessarily valid. They found that some of them are fake news, and they even have identified some accounts were intentionally distributing fake news publicly.
\end{abstract}

Keywords: Information experience; social media; first-time voters; presidential election 


\section{PENDAHULUAN}

17 April 2019 merupakan tanggal yang dipilih untuk diselenggarakannya pesta demokrasi di Indonesia. Pada tahun ini pemilihan calon anggota legislatif dilaksanakan serentak dengan pemilihan calon presiden dan wakil residen. Oleh karena hal tersebut, nama calon presiden dan wakil presiden telah terlebih dahulu muncul tanpa menunggu hasil pemilihan calon anggota legislatif, perihal tersebut berbeda dengan pelaksanaan pemilu tahun 2014 silam. Joko Widodo dan Prabowo Subianto adalah dua nama yang sudah tidak asing di telinga masyarakat Indonesia. Kedua nama tersebut kembali mencuat dan bersaing sebagai kandidat pasangan calon presiden periode tahun 2019-2024 dengan menggandeng nama calon wakil presiden mereka masingmasing. Ma'ruf Amin digandeng oleh Joko Widodo sedangkan Sandiaga Uno oleh Prabowo Subianto.

Meskipun kedua nama tersebut telah lama muncul dalam kancah persaingan pemilihan calon presiden namun mereka masih perlu melakukan kampanye dengan memanfaatkan media informasi yang tersedia. Selain kegiatan tersebut, Komisi Pemilihan Umum (KPU) juga menyelenggarakan debat antar calon presiden dan calon wakil presiden yang disiarkan melalui televisi dan media sosial YouTube. Kegiatan ini dimaksudkan untuk memberikan informasi kepada masyarakat mengenai profil, visi, misi, dan program kerja yang menjadi prioritas bagi calon presiden dan calon wakil presiden. Diharapkan melalui kegiatan tersebut masyarakat memiliki informasi dan preferensi dalam memilih calon presiden dan wakil presiden.

Prinsip dasar teori demokrasi adalah bahwa pilihan pemilih harus didasarkan pada pemikiran yang matang tentang masalah-masalah politik (Bode, Vraga, Borah, \& Shah, 2014). Pemikiran tersebut didasarkan dari akumulasi pengalaman informasi yang didapatkan dalam dunia nyata. Jika warga negara pemilih dalam pemilu tidak berinformasi dengan baik (well informed), maka keputusan mereka dalam memilih tokoh politik dalam pemilu tidak dapat mencerminkan kepentingan mereka sebenarnya, perihal tersebut tentunya mengancam cita-cita demokrasi (Lee \& Xenos, 2019). Oleh karena itu penting bagi pemilih terutama pemilih pemula untuk berinteraksi dengan informasi guna memperolah basis pengetahuan politik.

Dewasa kini kemasan informasi sangatlah beragam. Informasi tidak hanya dikemas dalam bentuk material tercetak namun juga digital. Salah satu media digital yang dekat dengan pemilih pemula adalah media sosial. Perkembangan media sosial sebagai salah satu sumber informasi sangatlah pesat (Fletcher \& Nielsen, 2017). Media sosial yang berbasis teknologi web 2.0 memungkinkan penggunanya untuk memperoleh informasi, dan bahkan menciptakan serta mendistribusikan informasi (Basset, 2013). Jika kita melihat realitas yang muncul mengenai lalu lintas informasi di dalam media sosial, kita akan menemui perilaku berbeda dari pengguna media sosial tersebut. Beberapa pengguna media sosial hanya membaca berita saja, namun sebagian yang lain juga membagikan berita kepada orang lain (Beam, Hutchens, \& Hmielowski, 2016). Aktifitas tersebut merupakan peluang dan ancaman bagi pemilih pemula yang masih mulai belajar mengenai politik.

Ancamannya adalah pemilih pemula yang kini didominasi oleh digital native merupakan individu yang tumbuh dan hidup ditengah pesatnya perkembangan teknologi. Umumnya mereka tidak memiliki masalah dan merasa percaya diri untuk terampil dalam mengoperasikan teknologi informasi, namun dibalik kelebihan tersebut terdapat bahaya laten yang tidak mereka sadari yaitu kelemahan meraka dalam mengevaluasi informasi yang didapatkannya (Mahmood, 2016; Saunders, 2018). Namun di balik ancaman tersebut, berlimpahnya informasi melalui media sosial juga menjadi peluang bagi pemilih pemula. Kerapnya pemilih pemula berinteraksi dengan informasi politik melalui media sosial, menjadi modal pengetahuan bagi mereka untuk memilih pasangan calon presiden dan wakil presiden yang dipercayainya. Fenomena tersebut menarik untuk dikaji dari sudut pandang pengalaman pemilih pemula berinteraksi dengan informasi politik. Fenomena tersebut dapat dikaji melalui salah satu perspektif dalam ilmu informasi, yaitu perspektif pengalaman informasi. Meneliti pengalaman informasi pemilih pemula membawa kita ke dalam keberadaan atau eksistensi mereka ketika mengeksplorasi informasi apa yang dialami 
dan bagaimana informasi tersebut dialami, bagaimana informasi hadir atau muncul, bagaimana informasi tercipta, dan bagaimana peran dan pengaruhnya dalam perilaku dan keputusan pemilih pemula memilih pasangan calon presiden dan wakil presiden (Bruce, Davis, Hughes, Partridge, \& Stoodley, 2014; Prasetyawan, 2019).

Davis (2015) mengemukakan bahwa melalui penelitian pengalaman informasi, kita dapat memperhatikan: bagaimana orang mengalami informasi, cara mereka terlibat dengan informasi, apa yang mereka alami sebagai informasi, sifat pengalaman mereka dengan informasi, serta pikiran dan perasaan mereka terkait dengan pengalaman informasi mereka. Davis kemudian menggambarkan pengalaman informasi memiliki tiga dimensi yang tidak dapat dipisahkan: (1) orang: individu dan pandangan dunia mereka, emosi, latar belakang, pikiran dan perasaan; (2) informasi: dalam berbagai bentuknya; (3) konteks: ruang (fisik dan atau virtual) di mana pengalaman terjadi (Miller, Davis, \& Partridge, 2019).

Dewasa ini sering kita temui penggunaan media sosial sebagai wadah diseminasi informasi bagi pasangan calon presiden dan wakil presiden guna menunjukan citra diri (image) yang positif. Namun tidak sedikit pula banyak kita temui penggunaan media sosial oleh tim sukses pasangan calon presiden dan wakil presiden, digunakan untuk menampilkan citra negatif pesaingnya. Pada era informasi saat ini penggunaan media sosial dianggap paling murah dan efektif menyasar masyarakat untuk membangun opini publik. Terlebih lagi bagi generasi digital native, media sosial merupakan bagian yang sangat diperlukan bagi kehidupan sosialnya. Dalam konteks pemilu para digital native mendominasi kriteria pemilih pemula. Pemilih pemula adalah pemilih yang baru pertama kali akan melakukan penggunaan hak pilihnya kerena telah memenuhi syarat untuk memilih. Pemilih pemula didominasi oleh masyarakat Indonesia yang berusia rentang 17-20 tahun (Simanjuntak, 2017). Menurut informasi dari Dirjen Dukcapil dalam Daftar Penduduk Pemilih Potensial Pemilu (DP4), terdapat pemilih pemula yang akan berusia 17 tahun pada tanggal 1 Januari 2018 sampai dengan 17 April 2019 sebanyak 5.035.887 jiwa (Fachrudin, 2018). Berdasarkan fakta tersebut, maka tidak mengherankan jika kita temui media sosial digunakan untuk membangun citra diri para pasangan calon presiden dan wakil presiden.

Media sosial merupakan suatu hal yang tidak dapat dipisahkan dari kehidupan sehari-hari para pemilih pemula (digital native). Digital native relatif menggunakan media sosial sebagai wadah belajar, tidak terkecuali dalam konteks mencari informasi mengenai politik. Media sosial digunakan sebagai media untuk belajar dan mengenal pasangan calon presiden dan wakil presiden. Melalui media sosial tersebut para pemilih pemula baik secara sengaja atau pun tidak, pasti akan berinteraksi dengan informasi seputar politik pencalonan presiden dan wakil presiden. Mengingat karakteristik era informasi pada saat ini dan kecanggihan teknologi web 3.0, informasi tidak lagi dicari, namun malah menghampiri mereka (García-Crespo, Gómez-Berbís, ColomoPalacios, \& García-Sánchez, 2011). Media sosial memungkinkan para pemilih pemula tidak hanya berinteraksi dengan informasi dari akun resmi (official account) pasangan calon presiden dan wakil presiden, mereka juga terhubung dengan beragam informasi yang telah diciptakan oleh orang lain dengan kepentingan tertentu. Pengalaman yang terbentuk ketika berinteraksi dengan informasi tersebut, banyak sedikitnya akan mempengaruhi persepsinya kepada kedua pasangan calon presiden dan wakil presiden (Reddy, 2014).

Berdasarkan uraian latar belakang masalah tersebut maka rumusan masalah yang diajukan dalam penelitian ini adalah bagaimana pengalaman informasi pemilih pemula menggunakan media sosial sebagai sarana pembelajaran politik dalam menentukan pilihan calon presiden.

\section{METODOLOGI PENELITIAN}

Penelitian ini merupakan penelitian kualitatif. Pendekatan yang digunakan adalah pendekatan fenomenografi yang berkonsentrasi pada upaya mengungkap berbagai pengalaman 
dalam fenomena yang sama (Creswell, 2013; Maybee, 2014; Wildemuth, 2009). Wawancara semi terstruktur digunakan dalam penelitian ini guna menggali lebih jauh pengalaman 10 partisipan (informan) yang tergolong sebagai pemilih pemula. Data yang diperoleh dianalisis dengan menggunakan thematic analysis, sehingga diperoleh pola (patern) yang muncul dari subjek dan objek yang dikaji (Heriyanto, 2019).

\section{HASIL DAN PEMBAHASAN}

Ada 3 tema utama yang saling berkaitan antara lain: media sosial sebagai media untuk mempelajari profil calon presiden, media sosial sebagai media belajar berdemokrasi dengan berpendapat dalam kolom komentar, dan media sosial sebagai media belajar menganalisis dan mengidentifikasi berita palsu seputar pemilu.

\section{Media Sosial Sebagai Media untuk Mempelajari Profil Calon Presiden}

Pembentukan opini publik merupakan salah satu hal yang menjadi prioritas dan perhatian para calon presiden. Maka tidak mengherankan jika para calon presiden memiliki tim sukses yang bertugas sebagai juru "rias". Berbagai riasan telah disiapkan melalui berbagai media tidak terkecuali media sosial melalui official account para calon presiden. Hal ini dilakukan sebagai upaya untuk membangun image positif calon presiden sehingga mampu memikat para konstituennya (Indrayani, 2012).

Tidak sedikit dari partisipan dalam penelitian ini yang mengaku mengikuti (follow) akun resmi (official account) media sosial milik kedua calon presiden. Para pemilih pemula yang menjadi partisipan berinteraksi dengan informasi yang disajikan dalam media sosial tersebut, melalui interaksi tersebut muncul berbagai ungkapan pengalaman. Melalui akun resmi tersebut para partisipan mencoba untuk membaca dan mengetahui jejak karir dan riwayat hidupnya. Partisipan lain mengungkapkan bahwa melalui akun resmi tersebut mereka dapat mengetahui kehidupan keseharian para calon presiden. Partisipan lain juga menyatakan pengalamannya, bahwa melalui akun resmi tersebut mereka mencoba mengetahui cara kedua calon presiden berinteraksi dengan masyarakat umum. Berikut salah satu kutipan wawancara ungkapan pengalaman informasi Panji yang mengikuti akun resmi calon presiden.

"Karena ingin melihat aktivitas mereka di sosial media. Apakah benar-benar memiliki sifat baik atau enggak. Intinya saya ingin melihat image dari kedua calon presiden tersebut melalui sosial media. Salah satu parameter saya melihat calon presiden yang ingin saya pilih ya dengan follow calon presiden."

Terdapat hal yang menarik dalam temuan penelitian ini terkait pengalaman pemilih pemula yang mengikuti (follow) official account media sosial milik calon presiden. Pengalaman tersebut diceritakan oleh Sasa, dia mengungkapkan bahwasanya hadirnya peran juru rias atau admin yang mengelola official account media sosial milik calon presiden menjadikan akun tersebut terkesan tidak humanis, kaku, dan tidak alami. Sasa membandingkannya dengan akun resmi milik tokoh politik lainnya yang dioperasikan oleh pemiliknya sendiri. Berikut kutipan wawancara dengan partisipan terkait hal tersebut.

"Aku kan follow Ridwan Kamil. Coba bandingkan, Ridwan Kamil tuh kayaknya yang megang dia sendiri ya, aku juga ngga tau ya. Dia bikin postingan habis mengunjungi ini-ini. Terus dia jelasin deskriptifnya itu ngga kaku, pakai bahasa dia dengan jokes dia. Jadi aku follow dia. Tapi kalau Jokowi kan mungkin dipegang admin. Jadinya kaku gitu loh, bahasanya ya bahasa gitu, mungkin karena dia presiden juga kan ya. Aku tuh suka bu Ani. Bu Ani bagus. Fotofotonya, captionnya pakai dua bahasa kan inggris sama Indonesia".

\section{Media Sosial Sebagai Media Belajar Berpendapat}

Para pelaku politik praktis menggunakan media sosial sebagai alat untuk mempengaruhi opini publik. Seperti yang telah dijelaskan pada sub bab sebelumnya, juru rias calon presiden telah siap dengan konstruksi berita yang diciptakannya. Kondisi tersebut ditambah atau diperkuat 
dengan tentara siber yang siap menyusup dan membubuhi komentar pada berita yang disajikan di media sosial (Margana, 2017).

Strategi yang dilancarkan oleh juru rias calon presiden nyatanya cukup ampuh dan menarik perhatian para pemilih pemula. Alih-alih fokus pada berita atau informasi yang disajikan pada media sosial, para memilih pemula justru lebih tertarik pada komentar yang diutarakan oleh netizen. Hal tersebut diceritakan oleh Viva ketika ia membaca berita yang didapatkannya dari berbagai media sosial, berikut kutipan wawancaranya.

“...terus yang paling seru sih melihatnya dari komentar. Karena dari komentar itu biasanya kita tahu, mana pendukung kubu 1 mana yang kubu 2. Biasanya kalau dia dukung Jokowi nih, dia jelek-jelekin Prabowo. Contoh nih ada satu postingan prabowo yang positif. Tapi langsung pendukung Jokowi itu komentar, ah itu bohong..."

Pengalaman yang berbeda terkait ketertarikan pemilih pemula membaca kolom komentar dari sebuah berita yang disajikan melalui media sosial diceritakan oleh Dede. Ia mengaku tertarik membaca kolom komentar, karena dapat membantunya memahami isi dan makna berita yang disajikan sesuai dengan bahasa yang lebih mudah dipahaminya. Berikut kutipan wawancara Dede.

"Iya. Kadang-kadang komentar orang juga membantu sih. Ya kan kadang-kadang ada orang yang menulis ulang ceritanya yang sepemikiran sama kita. Kayak sesuai dengan bahasa kita. Jadi lebih gampang dipahami. Jadi kayak suka cari informasinya dari komen-komen orang, atau nggak kayak lihat pendapat-pendapat orang lain. Lihat dari sudut pandang orang lain".

Temuan yang menarik lainnya adalah beberapa dari partisipan menyatakan pernah terpancing untuk turut berkomentar dan memberikan pendapat terkait isu dari berita yang disajikan. Salah satu pengalaman tersebut diceritakan oleh Viva.

“...Kan Jokowi bilang kalau presiden ngga boleh coba-coba. Nah terus banyakyang bilang gini, iya presiden ngga boleh coba-coba, tapi bapak aja salah bilang nyebutin ini. Nah itu tuh aku greget banget sama komentar itu. Mereka tuh tau hanya sekedar tau doang. Ngga tau latar belakangnya. Mereka hanya tau dari postingan-postingan, video-video. Aku tuh gregetnya gini, kalau mereka memang cuma tau dari postingan video dan ngga tau latar belakangnya ya ngga usah komen. Aku kemarin komentar itu sih. Aku ngga ada nge-tag ke siapa-siapa. Cuman aku tuh greget banget. Aku tulis di kolom komentar gini, Wahai Negara +62 kalau ngga tau latar belakangnya nggak usah komen deh, malu-maluin negara ini aja".

April juga menceritakan hal serupa terkait pengalamannya turut berkomentar pada tautan berita yang terdapat di media sosial, berikut kutipan wawancaranya.

“...Terus misal dia itu emang ngga sesuai faktanya, kadang aku pernah menyelipkan beberapa di komen gitu, untuk pembenaran aja sih".

Pengalaman yang diceritakan partisipan tersebut menengarai tumbuhnya sikap kritis dan demokratis dalam menghadapi isu yang berkembang di media sosial. Partisipan memiliki kepedulian dan keberanian untuk mengemukakan pendapatnya. Partisipan berupaya mengemukakan pendapat yang diyakininya lebih objektif dibandingkan dengan komentar netizen yang muncul pada media sosial.

\section{Media Sosial Sebagai Media Belajar Mengidentifikasi Berita Palsu}

Berita palsu atau hoax sudah menjadi hal tidak asing bagi masyarakat yang hidup di era informasi kini. Maraknya berita palsu telah menjadi keprihatinan yang berkembang di seantero dunia (Shin, Jian, Driscoll, \& Bar, 2018). Setiap individu kini, melalui media teknologi komunikasi dan informasi dapat dengan mudah memperoleh informasi dan menyebarluaskannya. Celakanya 
terkadang saat seseorang menyebarkan informasi tersebut, ia tidak memeriksa kesahihan informasi yang dibaginya. Artinya tanpa dia sadari atau bahkan memang disadari, bahwa dia telah menyebarluaskan berita palsu. Berbagai bentuk berita palsu yang menyebar di tengah masyarakat, baik itu berupa teori konspirasi ataupun desas desus tidak berdasar yang sengaja dihembuskan guna kepentingan tertentu.

Melalui media sosial para pemilih pemula akan mendapatkan berbagai informasi dari berbagai arah. Informasi yang berasal dari berbagai sumber tersebut akan mendatangi mereka. Tidak hanya sumber informasi terpercaya, namun juga sumber informasi yang tidak dapat dipertanggungjawabkan pun akan menghampiri para pemilih pemula. Kini berita berdasar fakta dan berita palsu sulit sekali untuk dibedakan. Terkadang berita berdasar fakta dipotong dan disajikan sedemikian rupa namun isinya berubah menjadi konteks yang sama sekali berbeda. Melihat fenomena tersebut, maka penting bagi para pemilih pemula memiliki ketrampilan untuk memilah dan memilih informasi politik yang didapatkannya dari media sosial.

Verifikasi informasi merupakan perilaku yang ditemukan dalam penelitian ini, terkait cara pemilih pemula mengidentifikasi berita palsu. Namun yang menarik dari temuan penelitian ini adalah pengalaman yang berbeda ketika melakukan verifikasi berita palsu di media sosial. Sebelum melakukan verifikasi, umumnya mereka mengidentifikasi apakah sebuah berita yang didapatkannya melalui media sosial merupakan berita palsu atau fakta.

Virgie menceritakan pengalaman menariknya ketika mengidentifikasi berita palsu, menurutnya setiap berita dalam bentuk potongan video diperlukan penerimaan yang kritis. Virgie menilai setiap potongan video yang beredar merupakan upaya dari pihak yang tidak bertanggung jawab untuk memanaskan suasana dan isu politik. Berikut adalah kutipan wawancaranya.

"Biasanya kalau potongan-potongan video gitu cuman buat manas-manasi. Aku sering liat di komentarnya juga panas. Gimana ya, bingung aku jelasinnya. Intinya aku kurang suka. Kenapa yang dimunculkan harus bagian yang itu. Yang biasanya jadi perbincangan banyak orang. Jadi menimbulkan banyak pro dan kontra".

Selain bersikap kritis terhadap berita yang diterima, partisipan lain juga menceritakan pengalamannya ketika mengidentifikasi berita palsu. Mereka memilih bersikap berhati-hati dan tidak terburu-buru menyebarkan berita tersebut, terlepas apakah berita tersebut akhirnya diketahui sebuah hoax atau fakta. Mereka memilih menyimak dan menunggu adanya berita lain yang memverifikasi berita tersebut. Seperti halnya pengalaman yang diceritakan Dede pada kutipan wawancara berikut ini.

"Ya ngga harus percaya dulu gitu. Ya kan pasti kita bisa mikir lah, ah nggak mungkin ini. Hoax itu kan pasti nanti bakalan ada yang mengklarifikasi. Pasti nanti ada aja yang suka mengklarifikasi. Yang penting ngga percaya dulu".

Temuan yang paling menarik adalah pengalaman para partisipan ketika melakukan evaluasi informasi berita politik yang ditemukannya melalui media sosial. Beberapa partisipan mengungkap bahwa mereka kerap mencari informasi pembanding yang dicarinya dari sumber lain. Seperti halnya pengalaman yang diceritakan oleh Aisqi pada kutipan wawancara berikut ini.

"Biasanya nggak hanya sekali baca. Berkali-kali dari berbagai informasi. Misalnya dapetnya dari instagram, kita cek di google. Kita cek lagi ke video (Youtube)".

Perilaku yang sama namun pengalaman yang berbeda diungkapkan oleh Dede. Pengalaman verifikasi informasi diutarakannya yaitu mengamati arus berita topik serupa yang mengalir dan lalu-lalang di hadapannya, menunggu para netizen mengungkapkan opininya, berharap mendapatkan informasi yang lebih terpercaya dan akurat. Berikut kutipan wawancara Dede terkait pengalamannya mengevaluasi informasi. 
"Misalnya ada berita nih. Kayak, ih ini berita apa sih. Terus ya udah baca berita tentang apa. Ya udah cari masalahnya apa atau orangnya siapa. Tinggal cari aja. Cari di google. Atau kayak searching instagramnya siapa gitu. Kan pasti banyak orang yang komentarkomentar. Ya udah baca aja dari komentarnya. Kan pasti ada sih orang yang menjelaskan lebih detail tentang masalahnya".

\section{DISKUSI}

Penelitian ini memiliki implikasi terhadap pengembangan kajian ilmu informasi khususnya pengalaman informasi (information experience). Kajian pengalaman informasi memang belum cukup populer jika dibandingkan dengan kajian perilaku informasi yang telah lahir jauh sebelumnya. Namun justru karena hal tersebut, membuka peluang yang sangat luas khususnya bagi para peneliti bidang ilmu perpustakaan dan informasi untuk turut mengembangkannya. Pengalaman informasi mengusung perspektif interpretatif, yang umumnya digunakan dalam berbagai penelitian sosial. Hal tersebut merupakan faktor yang mengakibatkan kajian pengalaman informasi memiliki domain yang luas dan fleksibel. Sehingga membuka peluang bagi peneliti untuk berkolaborasi dengan disiplin ilmu lain, guna mengungkap fenomena sehari-hari yang terjadi dalam konteks pengalaman informasi (Prasetyawan, 2019).

Temuan dalam penelitian ini memberikan informasi mengenai bagaimana para pemilih pemula menggunakan media sosial untuk berinteraksi dengan calon presiden pilihannya. Temuan tersebut mengindikasikan pentingnya bagi para calon presiden yang dipilih untuk mampu menunjukan image yang diharapkan oleh masyarakat umum (Indrayani, 2012). Temuan lain dalam penelitian ini menunjukan bahwa kini media sosial merupakan diversifikasi dalam komunikasi politik. Media sosial memainkan peran penting dalam melibatkan para pemilih pemula dalam diskusi politik atau bahkan menggiring opini mereka. Temuan serupa diungkapkan pada penelitian sebelumnya yang mengindikasikan peran media sosial sebagai ruang publik bagi masyarakat umum untuk berdiskusi tentang politik (Barnidge, 2015; Yang, Barnidge, \& Rojas, 2017). Isu berita palsu atau hoax yang kian sering terdengar dan menjadi perhatian, memunculkan kepercayaan diri terhadap kemampuan mengidentifikasi berita palsu atau hoax (Park \& Rim, 2019). Temuan dalam penelitian ini juga menunjukan hal serupa, melalui media sosial para pemilih pemula mampu bersikap kritis terhadap berita politik yang didapatkannya melalui media sosial.

Implikasi praktis dari penelitian ini adalah memberikan wawasan bagi berbagai pihak baik instansi pemerintah, instansi swasta, maupun masyarakat umum. Melalui hasil penelitian ini berbagai pihak tersebut dapat mengambil langkah strategis sesuai dengan kepentingan dan tujuannya.

\section{KESIMPULAN}

Media sosial telah merubah cara manusia berinteraksi dan berkomunikasi tidak terkecuali bagi para pemilih pemula. Media sosial kini telah menjadi panggung utama bagi para politisi untuk menciptakan image dan membangun opini masyarakat. Panggung tersebut menjadi tontonan utama para pemilih pemula untuk belajar dan mengenal dunia politik. Belajar dan mengenal politik melalui media sosial, para pemilih pemula memiliki perilaku informasi yang serupa namun dengan pengalaman informasi yang beragam.

Sebagai salah satu kajian pengalaman informasi, penelitian ini berkontribusi dalam memperkaya pemahaman mengenai bagaimana pemilih pemula mengalami informasi sebagai bagian dari kehidupannya belajar politik. Penelitian ini telah membuka peluang bagi penelitian selanjutnya yang memiliki fokus serupa (pengalaman informasi dan politik), untuk turut juga mengkaji media tradisional seperti alat peraga kampanye atau media televisi bagi pemilih pemula sebagai media belajar politik. 


\section{DAFTAR PUSTAKA}

Barnidge, M. (2015). The role of news in promoting political disagreement on social media. Computers in Human Behavior, 52, 211-218. https://doi.org/10.1016/j.chb.2015.06.011

Basset, H. (2013). 6-Enterprise 2.0 and Web 3.0. In H. Basset, D. Stuart, D. Silber, \& F. Boutin (Eds.), From Science 2.0 to Pharma 3.0 (pp. 169-193). https://doi.org/10.1016/B978-184334-709-5.50006-5

Beam, M. A., Hutchens, M. J., \& Hmielowski, J. D. (2016). Clicking vs. sharing: The relationship between online news behaviors and political knowledge. Computers in Human Behavior, 59, 215-220. https://doi.org/10.1016/j.chb.2016.02.013

Bode, L., Vraga, E. K., Borah, P., \& Shah, D. V. (2014). A New Space for Political Behavior: Political Social Networking and its Democratic Consequences. Journal of Computer-Mediated Communication, 19(3), 414-429. https://doi.org/10.1111/jcc4.12048

Bruce, C., Davis, K., Hughes, H., Partridge, H., \& Stoodley, I. (2014). Information Experience: New Perspectives and Research Directions. In Library and Information Science (Vol. 9, pp. 315320). https://doi.org/10.1108/S1876-056220140000010016

Creswell, J. W. (2013). Qualitative Inquiry \& Research Design: Chosing Among Five Approaches (Third Edit). SAGE.

Fachrudin, A. (2018, Oktober). Menyelamatkan Pemilih Pemula [Detik News]. Retrieved March 18, 2019, from Detik News website: https://news.detik.com/kolom/d4240110/menyelamatkan-pemilih-pemula

Fletcher, R., \& Nielsen, R. K. (2017). Are News Audiences Increasingly Fragmented? A CrossNational Comparative Analysis of Cross-Platform News Audience Fragmentation and Duplication: Are News Audiences Increasingly Fragmented? Journal of Communication, 67(4), 476-498. https://doi.org/10.1111/jcom.12315

García-Crespo, Á., Gómez-Berbís, J. M., Colomo-Palacios, R., \& García-Sánchez, F. (2011). Digital libraries and Web 3.0. The CallimachusDL approach. Computers in Human Behavior, 27(4), 1424-1430. https://doi.org/10.1016/j.chb.2010.07.046

Heriyanto, H. (2019). Implementasi Thematic Analysis dalam Penelitian Ilmu Perpustakaan dan Informasi. ANUVA: Jurnal Kajian Budaya dan Ilmu Perpustakaan, 3(1), 27-31. https://doi.org/10.14710/anuva.3.1.27-31

Indrayani, I. I. (2012). Media dan Politik Citra dalam Politik Indonesia Kontemporer. Scriptura, 3(2). https://doi.org/10.9744/scriptura.3.2.129-139

Lee, S., \& Xenos, M. (2019). Social distraction? Social media use and political knowledge in two U.S. Presidential elections. Computers in Human Behavior, 90, 18-25. https://doi.org/10.1016/j.chb.2018.08.006

Mahmood, K. (2016). Do People Overestimate Their Information Literacy Skills? A Systematic Review of Empirical Evidence on the Dunning-Kruger Effect. Communications in Information Literacy, 10(2). Retrieved from http://www.comminfolit.org/index.php?journal=cil\&page=article\&op=view\&path\%5B $\% 5 \mathrm{D}=\mathrm{v} 10 \mathrm{i} 2 \mathrm{p} 199 \& \mathrm{path} \% 5 \mathrm{~B} \% 5 \mathrm{D}=243$

Margana, A. (2017, September 30). Opini Publik dari Media Sosial. Retrieved from Media Indonesia website: https://mediaindonesia.com/read/detail/124901-opini-publik-darimedia-sosial

Maybee, C. (2014). Experiences of Informed Learning in the Undergraduate Classroom. In Library and Information Science (Vol. 9, pp. 259-274). https://doi.org/10.1108/S1876056220140000010013

Miller, F., Davis, K., \& Partridge, H. (2019). Everyday life information experiences in Twitter: A grounded theory. Information Research, 24(2), paper 824.

Park, K., \& Rim, H. (2019). Social media hoaxes, political ideology, and the role of issue confidence. Telematics and Informatics, 36, 1-11. https://doi.org/10.1016/j.tele.2018.11.001

Prasetyawan, Y. Y. (2019). Pengalaman Informasi (Information Experience) Sebuah Alternatif Perspektif Komprehensif dalam Kajian Ilmu Informasi dan Perpustakaan. ANUVA: Jurnal 
Kajian Budaya dan Ilmu Perpustakaan, 3(2), 101-108. https://doi.org/10.14710/anuva.3.2.101-108

Reddy, V. (2014). Information Experience in the Context of Information Seeking Methods by Prospective Students. In Library and Information Science (Vol. 9, pp. 295-312). https://doi.org/10.1108/S1876-056220140000010015

Saunders, L. (2018). Information Literacy in Practice: Content and Delivery of Library Instruction Tutorials. The Journal of Academic Librarianship, 44(2), 269-278. https://doi.org/10.1016/j.acalib.2017.12.022

Shin, J., Jian, L., Driscoll, K., \& Bar, F. (2018). The diffusion of misinformation on social media: Temporal pattern, message, and source. Computers in Human Behavior, 83, 278-287. https://doi.org/10.1016/j.chb.2018.02.008

Simanjuntak, N. Y. (2017, November 16). Sosialisasi Kepada Pemilih Pemula [Kominisi Pemilihan Umum Republik Indonesia]. Retrieved March 18, 2019, from Kominisi Pemilihan Umum Republik Indonesia website: https://kpu.go.id/index.php/post/read/2017/5154/Sosialisasi-Kepada-Pemilih-Pemula

Wildemuth, B. M. (2009). Applications of social research methods to questions in information and library science. Westport: Library Unlimited.

Yang, J., Barnidge, M., \& Rojas, H. (2017). The politics of "Unfriending": User filtration in response to political disagreement on social media. Computers in Human Behavior, 70, 22-29. https://doi.org/10.1016/j.chb.2016.12.079 